\title{
Physical manifestations of violence on children in the teeth, jaw, and facial areas in odontology forensic
}

\author{
Ajeng Wulandari*, Eriska Riyanti*, Fahmi Oscandar** \\ *Department of Pedodontics Faculty of Dentistry Universitas Padjadjaran \\ **Department of Dentomaxillofacial Radiology Faculty of Dentistry Universitas Padjadjaran
}

\begin{abstract}
Introduction: Child abuse often occurs among children and leaves a negative impact on the rest of their life. The purpose of this study was to determine the significance of the manifestation of violence on the teeth, jaw, and facial from the view of odontology forensic. Methods: This study was descriptive research. Forty subjects were involved, which were taken using the purposive sampling method. Data obtained in the form of questionnaires and presented in tabular form. Results: The result has shown that $20.32 \%$ of the subjects had oral injuries. $20.32 \%$ of the subjects had oral bleeding, followed by bleeding gums, tooth bleeding, tooth mobility, tooth fractures, swollen gum, and swollen lips-injuries to the facial area including laceration, incision and burns. The highest incidence was $70.59 \%$ of facial injuries involving the middle third of the face, followed by the upper third, and then lower third of the face. Conclusion: The most manifestation of violence among the child abuse case involved are observed in dental and facial areas.
\end{abstract}

Keywords: Child, facial, jaw, physical violence.

\section{INTRODUCTION}

The current population of children in Indonesia is very large and mostly live in low socioeconomic circumstances, this factor can lead to an increase in cases of violence in children. This happens because parents who experience high levels of stress tend to release their irritation on their children. Another problem that arises is that children who become victims of violence tend to be covered by either the child, parents, or even his family. The main victim of child abuse is mostly preschool children. However, according to The National Society for Prevention of Cruetly to Children in 1990, those who committed acts of violence in most of the cases were biological parents. The stepfather or stepmother, the person who replaces the parent's position, and the other strangers (neighbor, male / female friend of the parent) can also be the perpetrator of the violence. Violence can be done by anyone who have varying levels of education, economy and social. ${ }^{1}$

The effects experienced by children who become victims of physical violence are very diverse. Usually, children will act similarly to others or even to their children later because they feel the things done by their parents is the right thing, or they also want others to experience the same feelings they have undergone. Age will reflect the personalities that distinguishes children 
and adults. However, defining children in terms of age can be problematic because of the use of different definitions by different countries and international institutions. Department of Child and Adolescent Health and Development, defines children as people under the age of 20. However, The Convention on the Rights of the Child defines children as persons under the age of $18 .^{2}$

Physical violence imposed on children is violence that can lead to a lifelong trauma for a child. It happens intentionally and is often done by a nanny (parents, siblings, babysitters / babysitters) who do not understand the correct childcare rules. ${ }^{3}$ There are several types of violence that occur in children, such as physical violence, sexual abuse, emotional abuse, and abandonment of children. In cases of sexual abuse of the child the manifestations may be seen in the oral cavity area, and from cases of physical violence there are lesions in the head and neck region (50\%), and in the face and intraoral (49-65\%). ${ }^{4}$ Oral cavities and orofacial areas are often into a center of physical violence, it can happen because a blow is directed into the mouth or inserting dangerous objects into the oral cavity to make the screaming child silent. In addition there are external injuries to the head, face, and mouth, as well as bleeding, or swelling of the outer ear canal, chapped lips, shaking or broken teeth, lacerations on the tongue and both blue eyes with no trauma to the nose. All of these can indicate persecution. ${ }^{5}$

Forensic dentistry can be used to reveal the events of human evil in the hope that a proper judicial process can be obtained. This is done by examining the physical condition of the survivors as well as those who have died, from the results of the examination through antemortem and postmortem data. Antemortem data is important data of the victim before the violent event occurs or when the victim is alive, which includes dental data, fingerprint data, and ownership data used or carried. In addition, there is also postmortem data which includes the victim's physical data obtained after a violent incident occurred, such as bruises on the skin, damage to the teeth or damage to the inside of a person's body. ${ }^{6}$

Physical violence due to blows in orofacial areas may result in tearing of the labialis frenulum. The incidence is common in children aged 6-18 months at the time the child starts learning to walk. However, in children younger than 6 months of age, they will usually have pathognomic or non-specific symptoms. ${ }^{7}$ Based on the background described above, the problem that can be identified is the manifestation of cases of physical violence in the teeth, jaw, and face areas. The purpose of this study was to find out the manifestations of physical violence in the dental, jaw, and facial areas in children for the forensic importance of odontology.

Advantages to be gained from this research include:Theoretically, it can provide information to students and dentists in recognizing the signs of physical abuse that occurs in children in areas of teeth, jaws and faces. Applicative, can be used as a consideration in seeing signs of physical violence.

Violence against children constitutes all forms of physical or emotional acts or behaviors, sexual abuse, neglect, commercial exploitation, or other exploitation, resulting in injuries or disabilities that interfere with the child's health, the child's survival, child development, or the dignity of the child done in the context of the relationship of responsibility. ${ }^{8}$

Violent injuries can be seen clearly as bruises, wounds, and abrasions. Below is a table that contains the age of damage and abrasions caused by violence. The purpose of this study is to research this case, and show the significance of the manifestation of violence to the teeth, jaw, and facial from the view of odontology forensic.

\section{METHODS}

The type of research was descriptive. The subject in this research was the students of Balarenik Shelter House Jakarta. The sampling technique was purposive sampling. The criteria of the subject were as follows: (1) Children aged 15-18, (2) Male and female, (3) Physically and mentally healthy, (4) Willing to fill in informed consent. The steps in the research process were research preparation, questionnaire making, and oral area observation.

\section{RESULTS}

The study was conducted on 40 children aged 15-18 years at Balarenik Shelter House. 
Tabel 1. Number of male and female

\begin{tabular}{ccc}
\hline No. & $\begin{array}{c}\text { Children in Balarenik } \\
\text { Shelter House }\end{array}$ & $\begin{array}{c}\text { Total numbers } \\
\text { of children }\end{array}$ \\
\hline 1 & Male & 25 \\
2 & Female & 15 \\
Total & & 40 \\
\hline
\end{tabular}

Table 2. Manifestations of violence

\begin{tabular}{clcc}
\hline No. & $\begin{array}{c}\text { Oral manifestations } \\
\text { of violence }\end{array}$ & $\begin{array}{c}\text { Number of } \\
\text { children }\end{array}$ & Percentage (\%) \\
\hline 1 & Oral injuries & 25 & 20.32 \\
2 & Gum injuries & 3 & 2.44 \\
3 & Tongue injuries & - & - \\
4 & Oral bleeding & 25 & 20.32 \\
5 & Gum bleeding & 10 & 8.13 \\
6 & Tongue bleeding & - & - \\
7 & Tooth bleeding & 17 & 13.82 \\
8 & Tooth mobility & 2 & 1.63 \\
9 & Tooth fracture & 15 & 12.19 \\
10 & Swollen tongue & - & - \\
11 & Swollen gum & 4 & 3.25 \\
12 & Swollen lips & 22 & 17.90 \\
\hline & Total & 123 & 100 \\
\hline
\end{tabular}

Table 3. Manifestations of violence in facial region

\begin{tabular}{cccc}
\hline No & $\begin{array}{c}\text { Manifestations of violence } \\
\text { in facial region }\end{array}$ & $\begin{array}{c}\text { Number of } \\
\text { children }\end{array}$ & $\begin{array}{c}\text { Percentage } \\
(\%)\end{array}$ \\
\hline 1 & Bruises & 30 & 66.67 \\
2 & Scratches & 10 & 22.22 \\
3 & Cuts & 3 & 6.67 \\
4 & Burns & 2 & 4.44 \\
\hline & Total & 45 & 100 \\
\hline
\end{tabular}

Table 4. Scar on upper, middle, lower third of face

\begin{tabular}{cccc}
\hline No. & Scar & $\begin{array}{c}\text { Number of } \\
\text { children }\end{array}$ & $\begin{array}{c}\text { Percentage } \\
(\%)\end{array}$ \\
\hline 1 & $\begin{array}{c}\text { Middle third of } \\
\text { the face }\end{array}$ & 36 & 70.59 \\
2 & $\begin{array}{c}\text { Lower third of the } \\
\text { face }\end{array}$ & 13 & 25.49 \\
3 & $\begin{array}{c}\text { Upper third of the } \\
\text { face }\end{array}$ & 2 & 3.92 \\
\hline & Total & 51 & 100 \\
\hline
\end{tabular}

Table 1 shows that the highest number of subjects are boys which is 25 people. In the table of research results, the percentage was not based on the number of subjects but the number of incidents that occur, because each subject can experience some indicators of violence. The percentage had shown the frequency of subject who experienced any manifestations of violence.

Based on the data in Table 2, it can be seen that the number of subjects who suffered from mouth injuries was 25 person (20.32\%), whereas 3 person $(2.44 \%)$ suffered injuries in the gums and no one suffered injuries to the tongue, bleeding on the tongue or swelling on the tongue. 25 person $(20.32 \%)$ had bleeding in the mouth, 10 person $(8.13 \%)$ had bleeding in the gums, 17 people $(13.82 \%)$ suffered bleeding in the teeth, 2 person $(1.63 \%)$ experienced tooth mobility, 15 people $(12.19 \%)$ suffered tooth fractures, 4 people $(3.25 \%)$ experienced swelling in the gums, and 22 people $(17.90 \%)$ experienced swelling on the lips. The percentage indicates the frequency of subjects who experienced any of the oral manifestations of violence.

Table 3 showed that the highest frequency of violence in facial area is 30 people $(66,67 \%)$ with bruises. In addition there were 10 subjects (22.22\%) with scratches, 3 subjects $(6.67 \%)$ with cuts, and 2 subjects (4.44\%) with burns. In addition the authors also obtained and recorded the incidence of the subjects who had scar on the upper third, middle third or lower third of their face in Table 4. From Table 4 it can be seen that the percentage of violence in the area of $1 / 3$ of the middle face is 36 people $(70.59 \%)$, in the area of $1 / 3$ lower face by 13 people $(25.49 \%)$ and in the area of $1 / 3$ upper face as many as 2 people (3.92\%). Manifestations of violence in the area of jaw were not found.

\section{DISCUSSION}

Physical violence can be defined as any act or act that could harm or interfere with the health and development of the child's physical or mental state. ${ }^{9}$ There are many factors that cause violence against children, namely parental education, economics, internal conflict in the family or alcohol-addicted parents and illegal drugs can be the cause of child abuse. Violence against children is divided into four types, namely physical violence, sexual abuse, emotional violence and abandonment of children. ${ }^{10}$ 
From the results of research that has been done, many cultural factors become one of the reasons for physical violence. Parents have the notion that punching or slapping is a normal form of punishment to educate their children. This has been the norm for generations. There was often a case of violence among boys, this could be seen as in Table 1. We can see more boys than girls were violently treated, this was because parents are more prone to allow boys to play outside than that of allowing girls to play outside.

In Table 2. the number of subjects who received violence in the oral part is as high as 25 people $(20.32 \%)$ this had happened because the parents often impose physical violence, such as slapping or hitting the child's mouth while crying or making a mistake, in order to make a child silent. From the results above, subjects who suffered from mouth injuries was 25 person (20.32\%), 3 person $(2.44 \%)$ suffered injuries in the gums and no one suffered injuries to the tongue, bleeding on the tongue or swelling on the tongue. 25 person $(20.32 \%)$ had bleeding in the mouth, 10 person $(8.13 \%)$ had bleeding in the gums, 17 people $(13.82 \%)$ suffered bleeding in the teeth, 2 person $(1.63 \%)$ experienced tooth mobility, 15 people $(12.19 \%)$ suffered tooth fractures, 4 people (3.25\%) experienced swelling in the gums, and 22 people $(17.90 \%)$ experienced swelling on the lips.

Based on the results of this research, lips area was more likely exposed to physical violence in comparison with the tongue. The area of the tongue is more protected by the lips because the lips have a layer of muscle that can protect the inside of the mouth. In addition, physical violence that occurs in the mouth area can be seen in the impact of extra oral areas and soft tissues, such as lips, and cheeks.

In Table 4.3 it can be seen that the frequency of acts of violence in the largest face area was 30 subjects $(66.67 \%)$, where they suffered bruises. The children admitted the parents or other strangers will usually impose violence in the area around the face, through slapping or punching them with blunt objects, as a result leaving a bluish mark on the child's face. As many as 10 subjects $(22.22 \%)$ suffered scratches, 3 subjects $(6.67 \%)$ had cuts, and 2 subjects $(4.44 \%)$ suffered burns.

Based on the results of the above table, bruising wounds were more often made compared to cuts and cuts wounds and burns. Table 4.4 showed there was also violence in the upper third, middle, and lower faces. The most common area is in the middle third of the face with the number of subjects of 36 people. The measurement of the height of the facial physiognomic face of the middle third is (1) Nasion ( $\mathrm{N})$ : the anterior portion of the nasofrontal suture at the median line and (2) Subnasion (Sn): lies in the junction of the lower portion of the nasal septum.

There was 13 subjects $(25.49 \%)$ who received violence previously in the area of lower third face whereas 2 subjects $(3.92 \%)$ had injuries in upper third of the face. Based on the results shown in the table above, the subjects often experience physical violence in the area of the middle third face compared to the area of the lower third face and upper one third of the face. A total of 36 subjects $(70.59 \%)$ suffered cases of violence in the said area. This happens because one-third of the middle face covers the cheek area, Children admitted that they often get violent behavior from the parents in the area around the cheek, such as being slapped or beaten which caused bruises.

Physical abuse of children can also be caused by a paradigm of wrong parents, they think that the child belongs to the parents so they are entitled to treat them anyway according to their wishes. The education status of the parents is also one of the factors that influence the existence of violence against children. Majority of parents only received primary school education backgrounds. Individuals with very low educated backgrounds tend to be less tolerant to their children and have limited perspective in addressing the problems they face. They do not think ahead about the risks of the behaviors that they are neglecting their children. If the subjective values are adopted without any regards to the objective values in social life, then all forms of violation of normal society values and existing cultural context will be regarded as a norm. ${ }^{11}$

Child abuse or any form of violence that occurs is intentional trauma or abuse of the child by a guardian who does not qualified in taking care of a child. Head and face injuries were frequently found in this case. The face and mouth area were also the usual target of violence by parents. Bite marks are often seen in cases of violence and sexual abuse. To prevent physical violence 
that occurs in children, parents need to improve knowledge about children developments, and the interaction between parents and children should be built on the basis of affection. The alertness of the dentist as a health worker to the early signs and symptoms of physical violence that occurred in children can save a child's life, especially in cases that can lead to the death of the child itself. Dentists have a separate role to break the chain of physical violence.

Therefore, the dentist should be aware of the signs of physical abuse and how to diagnose physical violence, such as signs of external injury to teeth, jaws, and face, and he must realize what steps ought to be taken if he finds out the child is a victim-; - of physical violence. WHO explains that physical violence and sexual violence include all forms of violence, and that often occur in the area of teeth and face.

Manifestations in cases of physical violence in the dental and facial areas include upper maxillary, anterior fractured teeth, alveolar bone fractures, laceration of the buccal and labial mucosa, lacerations to the frenulum and bruises of the lips, face and neck. The percentage of these incidents had increased from 3.3 to $41 \%$. This is due to the increasing reported cases of violence due to low level of public awareness and the tendency to isolate themselves in cases of physical violence that occurred.

\section{CONCLUSION}

The most manifestation of violence among the child abuse case involved are observed in dental and facial areas. The presence of injuries can be found in the mouth area such as oral bleeding and the tooth mobility.

\section{REFERENCES}

1. Bowers $\mathbf{C M}$. Forensic dental evidence an investigator's handbook. $1^{\text {st }}$ ed 2004. p. 117-9.

2. WHO. Consultation on Child Abuse Prevention. 1999.

3. Clark D (ed). Practical Forensic Odontologi. Oxford: Butterworth-Heinemann 1992.

4. Departemen Kesehatan Republik Indonesia. Pedoman rujukan kasus kekerasan terhadap anak. 2007. p. 18-53.

5. Vale GL. Dentistry's role in detecting and preventing child abuse. Forensic Dentistry. New York: CRC Press. 1997. p. 161-76

6. Yayasan Matahariku. Informasi dasar perkembangan anak dan kekerasan anak. Bandung: yayasan matahariku. 2003. p. 6-25.

7. Suyanto B, Hariadi SS. Krisis dan Child Abuse. Surabaya: Airlangga University Press. 2002. p. 114-22

8. Smile Dental Jurnal, 2009 Forensic Odontology. http://www.smiledentaljournal.com. 